\title{
\#USGS
}

Prepared in Cooperation with the Arizona Geological Survey

\section{Preliminary Bedrock Geologic Map of the Blythe 30' x 60' Quadrangle, California and Arizona}

Compiled by Paul Stone, Jon E. Spencer, and L. Sue Beard

Pamphlet to accompany

Open-File Report 2021-1097

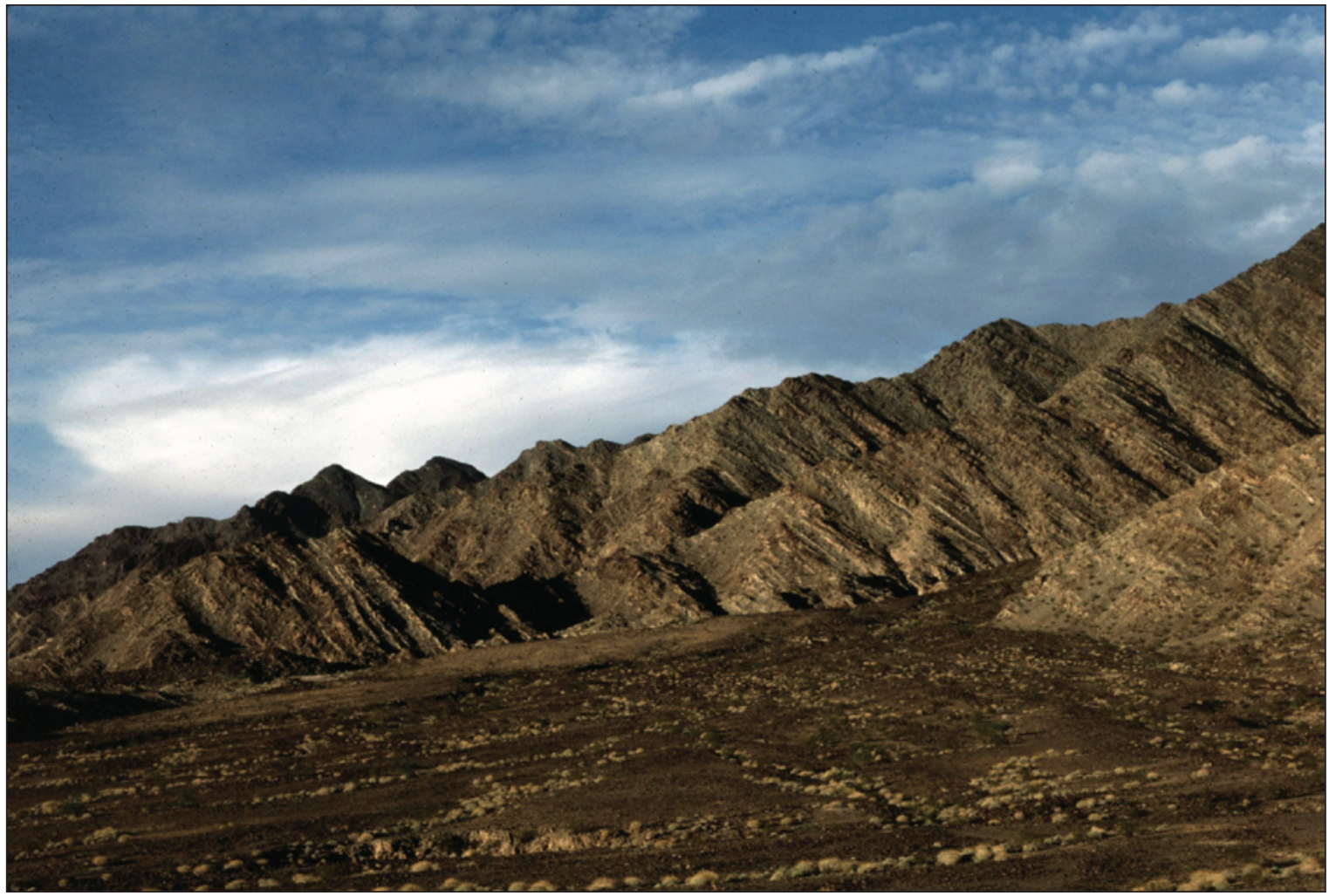

U.S. Department of the Interior

U.S. Geological Survey 


\section{U.S. Geological Survey, Reston, Virginia: 2022}

For more information on the USGS — the Federal source for science about the Earth, its natural and living resources, natural hazards, and the environment-visit https://www.usgs.gov or call 1-888-ASK-USGS.

For an overview of USGS information products, including maps, imagery, and publications, visit https://store.usgs.gov.

Any use of trade, firm, or product names is for descriptive purposes only and does not imply endorsement by the U.S. Government.

Although this information product, for the most part, is in the public domain, it also may contain copyrighted materials as noted in the text. Permission to reproduce copyrighted items must be secured from the copyright owner.

Suggested citation:

Stone, P., Spencer, J.E., and Beard, L.S., comps., 2022, Preliminary bedrock geologic map of the Blythe 30' x 60' quadrangle, California and Arizona: U.S. Geological Survey Open-File Report 2021-1097, 1 sheet, scale 1:100,000, 10-p. pamphlet, https://doi.org/10.3133/ofr20211097.

Associated data for this publication:

Stone, P., Spencer, J.E., and Beard, L.S., 2022, Digital data for the preliminary bedrock geologic map of the Blythe $30^{\prime} \mathrm{x}$ 60' quadrangle, California and Arizona: U.S. Geological Survey data release, https://doi.org/10.5066/P9YUU64Z.

ISSN 2331-1258 (online)

Cover. Photograph of west side of McCoy Mountains, California, showing south-dipping strata of McCoy Mountains Formation near McCoy Spring. Photograph by Paul Stone, U.S. Geological Survey. 


\section{Contents}

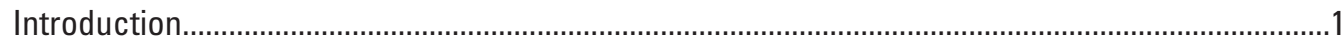

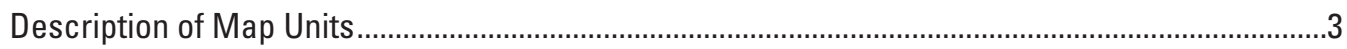

Acknowledgments

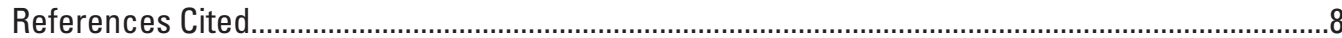

\section{Figures}

1. Map of Blythe $30^{\prime} \times 60^{\prime}$ quadrangle showing bedrock outcrop areas (shaded) and geographic locations noted in text.

\section{Conversion Factors}

International System of Units to U.S. customary units

\begin{tabular}{lll}
\hline \multicolumn{1}{c}{ Multiply } & \multicolumn{1}{c}{ By } & To obtain \\
\hline centimeter $(\mathrm{cm})$ & 0.3937 & inch (in.) \\
millimeter $(\mathrm{mm})$ & 0.03937 & inch (in.) \\
meter $(\mathrm{m})$ & 3.281 & foot (ft) \\
kilometer $(\mathrm{km})$ & 0.6214 & mile (mi) \\
meter $(\mathrm{m})$ & 1.094 & yard (yd) \\
\hline
\end{tabular}

\section{Datum}

Vertical coordinate information is referenced to the National Geodetic Vertical Datum of 1929.

Horizontal coordinate information is referenced to the North American Datum of 1927 (NAD 27).

Altitude, as used in this report, refers to distance above the vertical datum.

\section{Abbreviations}

$\begin{array}{ll}\text { AZGS } & \text { Arizona Geological Survey } \\ \mathrm{K}-\mathrm{Ar} & \text { potassium-argon } \\ \mathrm{Ma} & \text { mega-annum } \\ \mathrm{U}-\mathrm{Pb} & \text { uranium-lead }\end{array}$




\title{
Preliminary Bedrock Geologic Map of the Blythe 30' x 60' Quadrangle, California and Arizona
}

\author{
Compiled by Paul Stone ${ }^{1}$, Jon E. Spencer ${ }^{2}$, and L. Sue Beard ${ }^{1}$
}

\section{Introduction}

The Blythe 30' x 60' quadrangle in southeastern California and southwestern Arizona (fig. 1) displays complex geology that includes Mesozoic contractional deformation, metamorphism, and magmatism in addition to Cenozoic extensional deformation and magmatism. Existing geologic map compilations (Stone, 1990, 2006a, b) predate recent geologic mapping efforts that contribute new insights into the stratigraphy and structure of this quadrangle. The map accompanying this pamphlet was compiled in collaboration with the Arizona Geological Survey (AZGS) to incorporate this recent mapping and thus provide an updated depiction of the quadrangle's geologic framework. The scope of the present map is limited to bedrock units of Miocene and older age because the younger deposits have not been mapped in enough detail across the quadrangle to support a systematic compilation.

The geology of the Blythe 30' x 60' quadrangle was originally compiled by Stone (1990). That map was later digitized, and the west half of the quadrangle was upgraded by Stone (2006b). At about the same time, digital data for the east half of the quadrangle were released by Stone (2006a). In the updated bedrock compilation depicted in the accompanying map sheet, the east half of the quadrangle incorporates detailed geologic mapping published since 1990 (Richard and others, 1993; Tosdal and Stone, 1994; Spencer and others, 2015, 2016; Gootee and others, 2017; Johnson and others, 2017; Strickland and others, 2017); the west half of the quadrangle is largely unchanged from the map of Stone (2006b).

An index map showing the primary sources of geologic mapping for this compilation is provided on the map sheet. Sources of mapping for the previous compilations of Stone (1990, 2006b) are provided in those publications. The digital data for this map compilation are presented separately (Stone and others, 2022).

For this compilation, we created a uniform set of map units to which we assigned the various units distinguished in the source maps. In some areas, particularly the southern Plomosa Mountains, this process was interpretive. For example, the map of Richard and others (1993) contains many Cretaceous or Jurassic sedimentary rock units that we assigned to the relatively small number of units we considered appropriate for the compilation. Some of our unit assignments there are questionable (denoted by queries) and alternative unit assignments might be possible. With respect to the geologic line work, we remained as true to the source mapping as possible, except for deletion of contacts separating units that we combined and faults of minor significance. An unpublished 1:100,000-scale geologic map of the Plomosa Mountains prepared by J.E. Spencer and S.M. Richard for the AZGS in 2014 was a useful guide for our compilation in that complex area.

Regionally significant geologic features exposed in the Blythe 30' x 60' quadrangle include (1) variably metamorphosed and deformed Paleozoic to early Mesozoic sedimentary rocks stratigraphically correlative with cratonal platform strata of the Colorado Plateau region (Hamilton, 1964, 1982, 1984; Miller, 1970; Stone and others, 1983; Yeats, 1985; Stoneman, 1985a, b); (2) Jurassic plutonic and volcanic rocks (Tosdal and others, 1989); (3) thick sequences of moderately to weakly metamorphosed sedimentary rocks of the Jurassic to Cretaceous McCoy Mountains Formation (Pelka, 1973; Harding, 1982; Harding and Coney, 1985; Tosdal and Stone, 1994; Barth and others, 2004; Spencer and others, 2011); (4) ductile folds and faults of the Late Cretaceous Maria fold and thrust belt (Reynolds and others, 1986; Richard and others, 1994; Salem, 2009); and (5) Miocene detachment faults in the Big Maria Mountains, Copper Peak area, and Plomosa Mountains (Hamilton, 1982; Spencer, 1984; Spencer and Reynolds, 1991; Spencer and others, 2018). The open-pit Copperstone Mine, 3 kilometers $(\mathrm{km})$ northeast of Copper Peak (fig. 1), yielded about 14,000 kilograms of gold from specular hematite and amethystine quartz along a north-dipping, lower Miocene low-angle normal fault cutting Jurassic volcanic rocks (Spencer and others, 1988, 2018; Arizona Gold Corp., 2020).

Strickland and others $(2017,2018 \mathrm{a})$ recently discovered that the Late Cretaceous to Paleogene Orocopia Schist crops out structurally below undated gneiss in the northern Plomosa Mountains. This discovery marks the northernmost exposure of Orocopia Schist found in western Arizona to date and suggests that the entire Blythe quadrangle is underlain by this extensive, tectonically underplated subduction complex (Haxel and others, 2015, and references therein). Other recent contributions include documentation of post-middle Miocene transtensional

\footnotetext{
${ }^{1}$ U.S. Geological Survey

${ }^{2}$ Arizona Geological Survey
} 


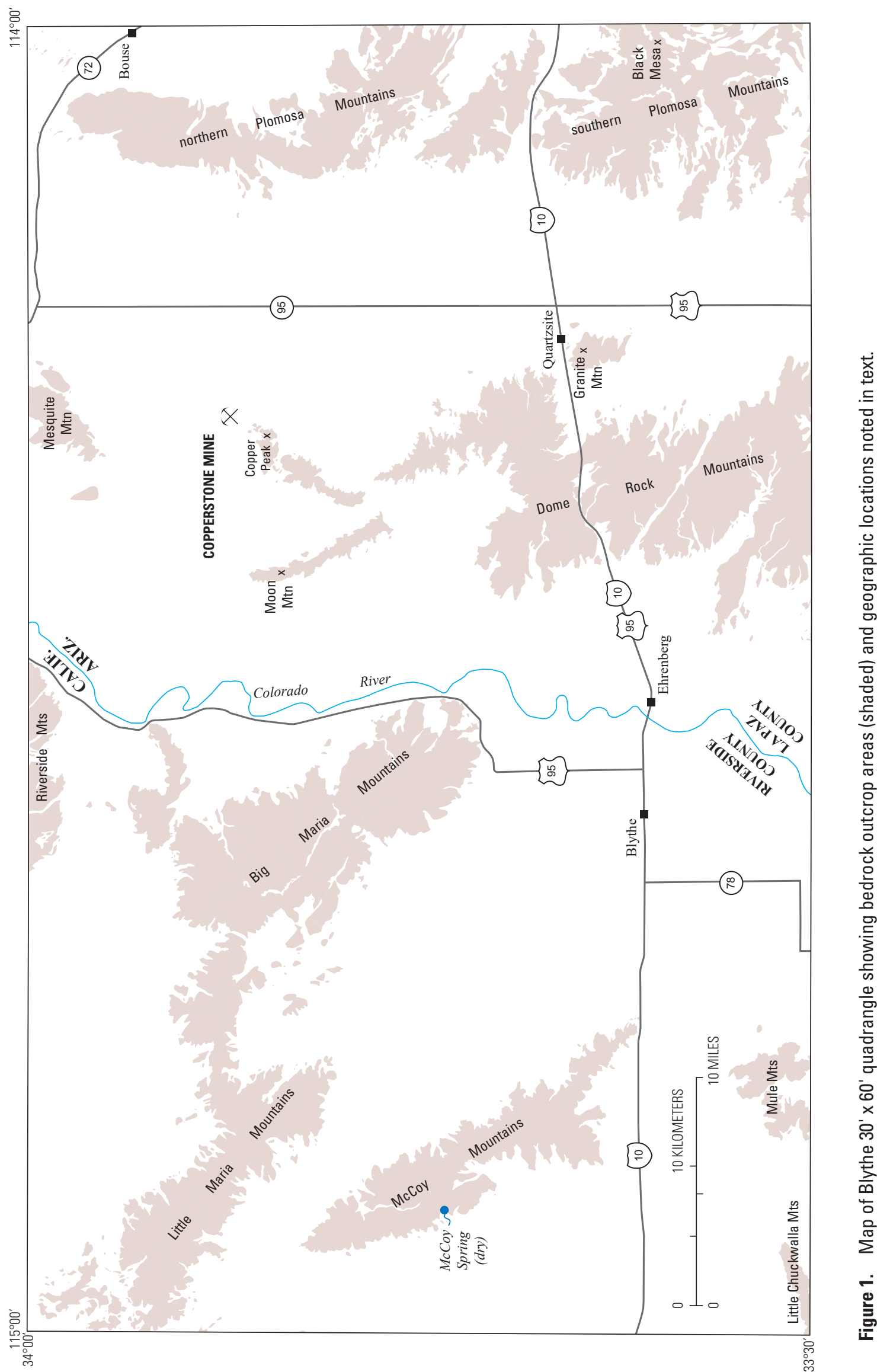


deformation in the northern Plomosa Mountains and at Mesquite Mountain (Strickland and others, 2018b) and determination of new age constraints on Late Cretaceous ductile deformation in the Big Maria Mountains (Flansburg and others, 2019).

Finally, in the west half of the quadrangle, we added a concealed, northwest-striking fault to account for about $50 \mathrm{~km}$ of apparent right-lateral offset of the base of the McCoy Mountains
Formation between the northern McCoy Mountains and the southern Dome Rock Mountains. Inferred movement on this fault, which was not shown by Stone (2006b), could have taken place at any time since the Late Cretaceous. The concealed fault trace partially coincides with that of the Cibola Fault of Richard (1993), who interpreted that fault to have undergone $7 \mathrm{~km}$ of right-lateral slip since 10 mega-annum (Ma, million years ago).

\section{DESCRIPTION OF MAP UNITS}

QTu Sedimentary deposits, undivided (Holocene to Miocene) - Consists of alluvial deposits derived from local bedrock uplands, alluvial deposits of the Colorado River, and the Bouse Formation (Stone, 2006a, b). Alluvial deposits range from fine-grained sand to boulder conglomerate and typically are nonconsolidated to weakly consolidated. Includes disturbed ground at Copperstone Mine

Tbm Basalt of Black Mesa (Miocene) - Olivine basalt flows that cap Black Mesa and other mesas in southern Plomosa Mountains. Whole-rock potassium-argon (K-Ar) age of 17.24 $\pm 0.43 \mathrm{Ma}$ (Shafiqullah and others, 1980)

Ts Sedimentary rocks (Miocene and Oligocene) - Conglomerate, sandstone, and minor limestone. In Dome Rock and southern Plomosa Mountains, consists of massive to indistinctly bedded, dissected fanglomerate containing angular to subrounded clasts of local derivation. In northern Plomosa Mountains and Moon Mountain area, consists of an upper unit of poorly sorted conglomerate having diverse clast compositions and a lower unit of arkosic sandstone, conglomerate, and limestone. Age based on regional correlations and geochronologic data from associated volcanic rocks

Tx Sedimentary breccia (Miocene and Oligocene)_-Unbedded, unsorted deposits of angular gravel, boulders, and slide blocks, commonly monolithologic, interpreted to have been deposited by landslides. Slide blocks are large, angular, generally brecciated blocks and slabs of Paleozoic sedimentary rocks, Jurassic volcanic or granitic rocks, and crystalline rocks of Proterozoic or Mesozoic age

Tsx Sedimentary rocks and sedimentary breccia, undivided (Miocene and Oligocene)—Mapped in Riverside Mountains

$\mathrm{Ti} \quad$ Felsic intrusive rocks (Miocene and Oligocene)-Fine-grained, hypabyssal intrusive rhyolite to dacite. Includes dacite in Big Maria Mountains that has a hornblende K-Ar age of about $22 \mathrm{Ma}$ (Martin and others, 1982)

Tv Volcanic rocks, undivided (Miocene and Oligocene)—Rhyolitic to basaltic volcanic rocks of diverse lithologic character. The most extensive outcrops, in central Plomosa Mountains, consist largely of dacite lava flows and flow breccia along with less common, bedded pyroclastic rocks including tuff. In northern Plomosa Mountains, consists largely of mafic volcanic rocks that are interstratified with sedimentary rocks (unit Ts). In southern Plomosa Mountains, includes welded tuff, rhyolite lava, andesite flows and domes, and minor sedimentary rocks. Outcrops near Copper Peak are basalt. In Riverside Mountains, includes andesite that has a whole-rock K-Ar age of 23.5 $\pm 1.0 \mathrm{Ma}$ (Martin and others, 1982). In Plomosa Mountains, includes rhyodacite that has a hornblende K-Ar age of

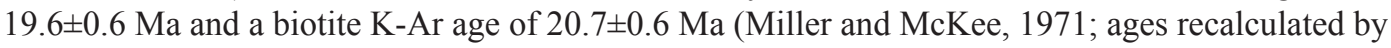
the method of Dalrymple, 1979)

Tg Granite (Miocene) - Southwest of Copper Peak, consists of unfoliated to weakly foliated, medium- to coarse-grained biotite granite and hornblende-biotite granite; the biotite granite has a uranium-lead (U-Pb) zircon age of 20.8 $\pm 3.2 \mathrm{Ma}$ (Knapp, 1989). In northern Plomosa Mountains, consists of medium-grained, biotite granite (Mudersbach granite of Scarborough and Meader, 1983, 1989) that has a U-Pb zircon age of 20.4+1.8/-2.1 Ma (Spencer and others, 2015)

Tic Mylonitic intrusive complex of northern Plomosa Mountains (Miocene) —Bimodal complex of leucocratic and intermediate-composition dikes, sills, and intrusive bodies (Strickland and others, 2017). Leucocratic rocks are mostly mylonitic and consist of tonalite, granodiorite, and rare granite. Intermediate-composition rocks are mostly nonmylonitic to protomylonitic and consist of diorite, less abundant quartz diorite and quartz monzodiorite, and rare quartz monzonite. Unit largely consists of layered tabular bodies subparallel to mylonitic foliation, although nonmylonitic dikes locally cut across well-foliated layers. U-Pb zircon ages of three mylonitic granodiorite sill and dike samples range from $22.58 \pm 0.55$ to $22.81 \pm 0.49 \mathrm{Ma}$; $\mathrm{U}-\mathrm{Pb}$ zircon age of one nonmylonitic diorite dike sample is $20.46 \pm 0.15 \mathrm{Ma}$ (Strickland and others, 2017) 
TKg Granite (Miocene to Cretaceous) - At Mesquite Mountain, consists of fine- to coarse-grained biotite granite that intrudes migmatitic gneiss (Knapp, 1989). At Copper Peak, consists of weakly to strongly foliated biotite granite (Copper Peak granite of Knapp, 1989). Undated; age based on lithologic comparison to nearby dated plutons

TXg Granitoid rocks (Miocene to Paleoproterozoic) - Small outcrops of dark granitoid rocks of unknown age in northern Plomosa Mountains (Spencer and others, 2015)

Orocopia Schist (Paleogene to Cretaceous) - Identified, mapped, and dated in northern Plomosa Mountains by Strickland and others (2017)

TKos Mylonitic schist - Quartzofeldspathic schist composed primarily of quartz, plagioclase, biotite, and muscovite, commonly containing graphitic plagioclase porphyroblasts 1 to $5 \mathrm{~mm}$ long. Commonly cut by mylonitic to protomylonitic dikes and sills, especially near intrusive contact with unit Tic. Paleogene to Late Cretaceous age of protolith deposition inferred from U-Pb analyses of detrital zircons (Strickland and others, 2017)

TKoa Amphibolite-Medium-grained hornblende amphibolite locally interlayered with mylonitic schist and leucocratic mylonitic sills. Includes abundant thin layers of quartzite (metachert) that locally are isoclinally folded

Kgb Gabbro and diorite (Cretaceous) - Weakly foliated gabbro and diorite in Big Maria Mountains. Late Cretaceous $\mathrm{U}-\mathrm{Pb}$ zircon ages of $74.72 \pm 0.47$ and $71.70 \pm 0.36 \mathrm{Ma}$ reported by M.E. Flansburg (University of Texas, written commun., 2020). Previously considered Jurassic (Hamilton, 1984; Stone, 2006b)

$\mathrm{Kg} \quad$ Granite (Cretaceous) - Variably foliated and lineated, medium- to coarse-grained biotite granite to granodiorite containing phenocrysts of potassium feldspar 1 to $5 \mathrm{~cm}$ long; present at northwest end of Little Maria Mountains (Ballard, 1990) and in northern Dome Rock Mountains-Moon Mountain area

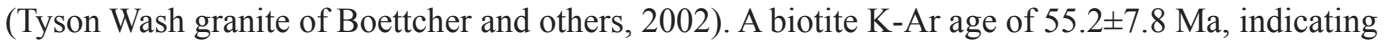
the minimum age of crystallization, has been reported from the Little Maria Mountains (Martin and others, 1982). Tyson Wash granite is Late Cretaceous based on a poorly constrained U-Pb zircon age of $83 \pm 25 \mathrm{Ma}$ and a more precise U-Pb age of $86 \pm 1 \mathrm{Ma}$ on sphene (Boettcher and others, 2002)

KJqm Quartz monzonite (Cretaceous or Jurassic) - Medium-grained, locally porphyritic quartz monzonite interpreted to intrude Paleozoic rocks and unit KXgn in northern Plomosa Mountains (Southern Cross pluton of Stoneman, 1985a, b). Locally contains orthoclase phenocrysts as long as $3 \mathrm{~cm}$

KJg Granite (Cretaceous or Jurassic) - Weakly foliated, fine-grained leucocratic granite interpreted to intrude Paleozoic rocks in northern Plomosa Mountains (Spencer and others, 2015)

KJd Diorite and andesite (Cretaceous and Jurassic) - Fine-grained mafic rocks intruded as irregular sills in the McCoy Mountains Formation and the sedimentary rocks of Apache Wash

KXgn Gneissic rocks, undivided (Cretaceous to Paleoproterozoic) - Strongly foliated and lineated mylonitic gneiss, augen gneiss, amphibolite, and migmatite interpreted to be derived primarily from Mesozoic plutonic rocks and Proterozoic metamorphic and plutonic rocks. Migmatitic gneiss of Mesquite Mountain is interlayered with synmetamorphic sills of medium- to coarse-grained biotite granite of Late Cretaceous age (67.2 \pm 1.4 Ma; Knapp, 1989)

McCoy Mountains Formation (Cretaceous and Jurassic?) —Primarily sandstone and conglomerate; minor shale, mudstone, and siltstone (Pelka, 1973; Harding, 1982; Stone and Pelka, 1989; Tosdal and Stone, 1994). Largely or entirely of fluvial origin (Harding and Coney, 1985). Weakly to moderately metamorphosed; beds commonly exhibit crosscutting foliation or cleavage. Age bracketed by underlying Late Jurassic ( $\sim 160 \mathrm{Ma})$ volcanic rocks (Jv) and by Late Cretaceous ( $\sim 73 \mathrm{Ma})$ plutonic rocks that intrude the formation in Coxcomb Mountains $30 \mathrm{~km}$ west of map area (Barth and others, 2004). Detrital-zircon U-Pb age determinations in map area indicate that members $\mathrm{C}$ through $\mathrm{L}$ were deposited after $\sim 110-120 \mathrm{Ma}$ (Barth and others, 2004); members A and B could be as old as Late Jurassic (Fackler-Adams and others, 1997). In Dome Rock Mountains, member F contains tuff having a U-Pb zircon age of about $79 \mathrm{Ma}$ (Tosdal and Stone, 1994) and numerous detrital zircon grains with dates between 80 and $108 \mathrm{Ma}$ (Spencer and others, 2011). Maximum thickness of formation about $8 \mathrm{~km}$. Members A-L are mapped individually in McCoy Mountains (Stone and Pelka, 1989); members A-B and C-E are combined as units KJmba and Kce in Dome Rock Mountains and southern Plomosa Mountains, where correlations with individual members are uncertain (Tosdal and Stone, 1994)

Kml Member L (Cretaceous) - Light-gray arkosic sandstone, conglomerate, and minor shale, all micaceous and phyllitic. Conglomerate clasts are quartzite, volcanic rocks, and granitic rocks. Contains detrital zircons as young as $\sim 84 \mathrm{Ma}$ (Barth and others, 2004). Base and top are faulted. Exposed thickness approximately $300 \mathrm{~m}$ 
Kmk Member K (Cretaceous) - Dark-gray, fine-grained arkosic to volcanic-lithic sandstone, light-gray phyllitic shale, and minor conglomerate. Conglomerate clasts are volcanic and granitic rocks. In fault contact with member L (member $\mathrm{Kml}$ ). Exposed thickness approximately $300 \mathrm{~m}$

Kmj Member J (Cretaceous) - Dark-gray, medium- to coarse-grained arkosic to volcanic-lithic sandstone and conglomerate, interbedded in lowermost part with minor light-gray arkosic sandstone. Conglomerate clasts are granitic and volcanic rocks. Thickness approximately $350 \mathrm{~m}$

Kmi Member I (Cretaceous) - Light-gray, medium- to coarse-grained arkosic and micaceous sandstone, conglomeratic sandstone, and conglomerate. Conglomerate clasts are quartzite, carbonate rocks, and granitic rocks. Thickness approximately $300 \mathrm{~m}$

Kmh Member H (Cretaceous) - Light-gray, fine-grained arkosic sandstone, conglomeratic sandstone, and shale, all micaceous and phyllitic. Contains detrital zircons as young as $\sim 87 \mathrm{Ma}$ (Barth and others, 2004). Thickness approximately 50 to $250 \mathrm{~m}$

Kmg Member G (Cretaceous) - Upper part consists of dark-greenish-gray, fine-grained arkosic to volcaniclithic sandstone. Lower part consists of light-gray to tan phyllitic and calcareous shale, tan calcareous sandstone, and conglomerate containing clasts of quartzite and carbonate rocks. Lower contact truncates beds in member $\mathrm{F}$ (unit $\mathrm{Kmf}$ ) at a low angle and is interpreted as an intraformational unconformity (Stone and Pelka, 1989). Locally contains late Early Cretaceous or younger fossil wood fragments (Pelka, 1973; Stone and Pelka, 1989). Thickness approximately 200 to $600 \mathrm{~m}$. Contains detrital zircons as young as $\sim 93 \mathrm{Ma}$ (Barth and others, 2004)

Kmf Member F (Cretaceous) - Light- to medium-gray, fine- to coarse-grained arkosic sandstone and conglomerate interbedded with less abundant light-gray phyllitic shale. Dark-gray to dark-greenishgray, very fine grained to fine-grained volcanic-lithic sandstone and siltstone present in upper part. Conglomerate clasts are granitic rocks, quartzite, volcanic rocks, and minor carbonate rocks. Fines upward from conglomerate and sandstone in lower part to very fine grained sandstone and siltstone in upper part. In Dome Rock Mountains, includes a lenticular, 5-m-thick tuff bed that has a U-Pb zircon age of 79 $\pm 2 \mathrm{Ma}$ (Tosdal and Stone, 1994). Uppermost part of member in McCoy Mountains contains detrital zircons as young as $\sim 91 \mathrm{Ma}$ (Barth and others, 2004). Strata equivalent to member $\mathrm{F}$ in Palen Mountains $3 \mathrm{~km}$ west of map area contain fragments of late Early Cretaceous or younger fossil wood (Pelka, 1973; Stone and others, 1987). Unconformable on underlying rocks of McCoy Mountains Formation in Dome Rock and southern Plomosa Mountains (Richard and others, 1993; Tosdal and Stone, 1994). Thickness in McCoy Mountains approximately 2,600 m

Kmec Members E, D, and C, undivided (Cretaceous) - Lithofeldspathic sandstone, siltstone, and mudstone in Dome Rock Mountains (Tosdal and Stone,1994). Questionably mapped in southern Plomosa Mountains to include various units of sandstone, mudstone, and conglomerate mapped by Richard and others (1993) as depositionally above unit KJmba

Kme Member E (Cretaceous) - Light-gray phyllitic shale, light-gray, dark-gray, and greenish-gray arkosic and volcanic-lithic sandstone, and minor conglomerate and calcareous rocks. Conglomerate clasts are quartzite, volcanic rocks, and granitic rocks. Grayish-orange, calcareous shale present near top. Contains detrital zircons as young as $\sim 165 \mathrm{Ma}$ (Barth and others, 2004). Thickness about 1,500 m

Kmd Member D (Cretaceous) - Dark-maroon phyllitic shale and silty to sandy shale interbedded with minor volcanic-lithic sandstone and conglomerate containing clasts of quartzite and volcanic rocks. Locally intruded by foliated diorite (not mapped). Thickness about $300 \mathrm{~m}$

Kmc Member C (Cretaceous) - Dark-gray to dark-greenish-gray, very fine grained to fine-grained volcaniclithic sandstone and siltstone, dark-gray to dark-greenish-gray mudstone, and minor conglomerate. Mudstone commonly contains brown calcareous pods and lenses of unknown origin. Conglomerate clasts are quartzite and volcanic rocks. Thickness about 1,200 m. Contains detrital zircons as young as $\sim 109 \mathrm{Ma}$ (Barth and others, 2004)

Jmba Members B and A, undivided (Jurassic?) — Interbedded quartzite, maroon mudstone, and brown sandy limestone in Dome Rock and southern Plomosa Mountains. Unconformably overlies Jurassic volcanic rocks (Jv) in both ranges and laps onto Proterozoic crystalline rocks in southern Plomosa Mountains (Richard and others, 1993; Tosdal and Stone, 1994)

Jmb Member B (Jurassic?) - Maroon mudstone and siltstone, commonly containing brown calcareous pods and lenses of unknown origin. Interbedded with minor tan quartzite and brown, recrystallized limestone. Thickness about $100 \mathrm{~m}$

Jma Member A (Jurassic?) - Tan, fine- to medium-grained quartzite and minor chert- and quartzite-clast conglomerate; interbedded with less abundant maroon mudstone and siltstone that commonly contain brown calcareous pods and lenses of unknown origin. Thickness about $350 \mathrm{~m}$. Unconformably overlies Jurassic volcanic rocks (unit Jv) in McCoy Mountains (Stone and Pelka, 1989); equivalent 
strata are interpreted to interfinger with underlying Late Jurassic volcanic rocks in Palen Mountains west of quadrangle (Fackler-Adams and others, 1997). Youngest known detrital zircons are $179 \mathrm{Ma}$ (Barth and others, 2004). Queried outcrops at south end of McCoy Mountains consist of strongly foliated and folded phyllite and minor quartzite that overlie metamorphosed volcanic rocks (JV?)

Sedimentary rocks of Apache Wash (Jurassic?) - Fining-upward sequence of sedimentary breccia, conglomerate, sandstone, and siltstone in southern Plomosa Mountains (Harding and Coney, 1985). Herein considered Late Jurassic(?) based on U-Pb analysis of detrital zircons (from unit Jaf) and on a U-Pb zircon age of $\sim 154 \mathrm{Ma}$ on a basaltic lava flow in a similar sequence just east of the map area (Spencer and others, 2011). Considered part of the McCoy Mountains Formation by Spencer and others (2011), but herein mapped as a lithologically distinct, possibly correlative unit in fault contact with the McCoy Mountains Formation as interpreted by Harding and Coney (1985). Total stratigraphic thickness approximately 1,900 m (Harding, 1980)

Fine-grained clastic rocks - Thin-bedded, locally laminated mudstone, siltstone, and very fine grained lithofeldspathic sandstone; thin beds of cobble conglomerate are also present. Unit generally weathers medium to dark gray, with phyllitic sheen; locally weathers greenish gray to brown. Analysis of detrital zircons from upper part of this unit yielded a youngest peak age of 160 to $170 \mathrm{Ma}$ (Spencer and others, 2011)

Sandstone - Medium-gray to greenish-gray, massive to medium-bedded, fine- to coarse-grained, lithofeldspathic sandstone and conglomeratic sandstone

Sandstone and conglomerate, undivided - Conglomerate, conglomeratic sandstone, sandstone, and siltstone. Locally intruded by Late Jurassic mafic sills and interbedded with Late Jurassic mafic lava flows (Spencer and others, 2011). Stratigraphic relations unclear

Conglomerate - Massive cobble to boulder conglomerate. Clasts include Jurassic volcanic rocks, lower Paleozoic sedimentary rocks, and Proterozoic granitoid rocks. Conglomerate clast assemblages vary across the outcrop area, reflecting local sediment sourcing (Richard and others, 1993)

Sedimentary breccia-Massive, unsorted breccia, massive coarse conglomerate, and megablock breccia containing clasts of Paleozoic sedimentary rocks and Jurassic volcanic rocks as long as several hundred meters (Richard and others, 1993)

Volcanic and sedimentary rocks, undivided (Jurassic and Triassic)-Mapped locally in Riverside and Big Maria Mountains, where units JV and JKS are not distinguished owing to metamorphism and deformation

Jv Volcanic rocks (Jurassic) - Consists mainly of gray to greenish-gray, rhyodacitic volcanic and metavolcanic rocks composed of a microcrystalline, felsic groundmass and phenocrysts of plagioclase, quartz, potassium feldspar, and minor biotite averaging about $2 \mathrm{~mm}$ in diameter. Generally unbedded; commonly foliated and metamorphosed to greenschist and lower amphibolite facies. Interpreted in some areas to have originated as ash-flow tuff, flows, and hypabyssal porphyry (Tosdal, 1988; Tosdal and others, 1989; Fackler-Adams and others, 1997). Considered part of the Middle to Late Jurassic Dome Rock sequence of Tosdal and others (1989). North of Black Mesa in the southern Plomosa Mountains, includes (1) volcanic-lithic sandstone and conglomerate derived entirely from Jurassic ash-flow tuff, and (2) massive dark-gray lava with local fragmental texture. In Riverside Mountains, includes greenstone of Hamilton (1964). In southern Dome Rock Mountains, large part of unit contains no fragmental textures and may represent a massive hypabyssal intrusion (Spencer and others, 2015). Reported U-Pb zircon ages of unit are about $165 \mathrm{Ma}$ in McCoy Mountains (Barth and others, 2004) and about $170 \mathrm{Ma}$ in Dome Rock Mountains (Tosdal and Wooden, 2015). U-Pb zircon ages from equivalent unit in Palen Mountains west of quadrangle range from about 155 to $175 \mathrm{Ma}$ (Fackler-Adams and others, 1997)

Jvbu Upper bedded unit-In Dome Rock Mountains, thin- to thick-bedded, fine-grained, felsic tuff and tuffaceous sedimentary rocks that form uppermost part of the Dome Rock sequence and concordantly underlie the McCoy Mountains Formation. Similar strata are present at the contact between units Jv and Jmba in southern Plomosa Mountains (Richard and others, 1993)

Jvbl Lower bedded unit - In Dome Rock Mountains, dark, thin-bedded, strongly metamorphosed sedimentary or volcaniclastic rocks that form the lowermost exposed part of the Dome Rock sequence. Rocks are composed largely of calc-silicate minerals, quartz, and biotite

Jvai Altered hpabyssal intrusive(?) rocks-In Dome Rock Mountains, sericitic schist containing small relict phenocrysts of quartz and feldspar

Jqp Quartz monzonite porphyry (Jurassic) - In Plomosa Mountains, massive, very light gray monzogranite intrusion containing abundant phenocrysts of potassium feldspar, plagioclase, and rounded quartz in a very fine grained groundmass. Similar to some rocks of unit JV but coarser grained (Richard and others, 1993) 
Plutonic rocks (Jurassic) — Porphyritic granitoid rocks ranging from granodiorite and quartz monzonite to quartz syenite, and equigranular rocks of varied composition including leucocratic granite, granodiorite, and diorite. Commonly metamorphosed and foliated. Most abundant rock type is medium- to coarse-grained, strongly foliated to unfoliated, porphyritic granodiorite to monzogranite characterized by potassium feldspar phenocrysts 1 to $5 \mathrm{~cm}$ long and by clotted mafic minerals, primarily biotite. Leucocratic granite is fine to coarse grained and unfoliated to weakly foliated; it commonly intrudes the porphyritic granitoid rocks. Fine-grained, foliated granodiorite and diorite are present locally. Considered part of the Middle to Late Jurassic Kitt Peak-Trigo Peaks superunit by Tosdal and others (1989). Uranium-lead zircon ages from rocks in map area are about $160 \mathrm{Ma}$ in Big Maria Mountains (L.T. Silver, oral commun. in Hamilton, 1982), 165 Ma in Mule Mountains (Tosdal, 1988), and 164-165 Ma in Dome Rock Mountains (Tosdal, 1988; Boettcher and others, 2002; Tosdal and Wooden, 2015). An unusually young uranium-lead zircon age of about $144 \mathrm{Ma}$ was reported for leucogranite in the western Big Maria Mountains by Salem (2009)

Jpl Leucocratic granite - Light-colored, fine- to medium-grained, equigranular to slightly porphyritic granite containing 2 percent or less mafic minerals. U-Pb zircon age of about 160 Ma reported in Dome Rock Mountains (Boettcher and others, 2002)

Jpd Foliated diorite to granodiorite-Dark-colored, fine- to medium-grained plutonic rocks that typically exhibit foliation defined by biotite and saussurite marginal to feldspar grains

JXg Granite (Jurassic or Paleoproterozoic) —Diverse, undated granitic intrusions of unknown age northwest of Black Mesa in southern Plomosa Mountains (Richard and others, 1993), intruded by unit Jqp

JXt Metamorphic tectonite (Jurassic or Paleoproterozoic) - Strongly foliated, fine-grained metaigneous rocks that contain scattered small porphyroclasts of quartz and feldspar in Plomosa Mountains; interpreted to be derived from Jurassic volcanic rocks or Paleoproterozoic volcanic or plutonic rocks (units Jv, Xv, Xgd) (Richard and others, 1993). Northern outcrop area includes tectonized lenses of Paleozoic strata

JXu Heterogeneous metamorphic rocks, undivided (Jurassic or Paleoproterozoic) —Includes schist, gneiss, and fine-grained siliceous rocks in Dome Rock Mountains that could be quartzite, metavolcanic rocks, or both

Jks Sedimentary rocks (Jurassic and Triassic) - Variably metamorphosed sedimentary rocks of diverse lithology; interpreted as broadly correlative with Triassic to Jurassic formations of the Colorado Plateau and eastern Basin and Range (Hamilton, 1982, 1984; Yeats, 1985; Ballard, 1990; Richard and others, 1993) and with the Buckskin and Vampire Formations of west-central Arizona (Reynolds and others, 1989). Where best exposed in Little Maria Mountains, unit generally consists of, in descending order, (3) fine-grained, locally crossbedded quartzite possibly equivalent to Jurassic Aztec Sandstone; (2) conglomeratic rocks of uncertain regional correlation containing clasts of quartzite, carbonate rocks, and granite; and (1) greenschist, gypsiferous schist, and calcareous quartzite possibly equivalent to Triassic Moenkopi Formation (Hamilton, 1982; Ballard, 1990). In Dome Rock Mountains, consists of quartzofeldspathic schist and micaceous marble with layers of quartzite and quartz-pebble metaconglomerate. In southern Plomosa Mountains, consists of massive purple-gray, cobble to boulder conglomerate considered part of the the Vampire Formation by Reynolds and others (1989)

kqm Quartz monzonite and monzodiorite (Triassic) - Porphyritic biotite quartz monzonite and hornblende monzodiorite exposed in Mule Mountains near south edge of map. Age is about 213 Ma based on $\mathrm{U}-\mathrm{Pb}$ analysis of zircon (Barth and others, 1990). Lithologically similar to Late Triassic Mount Lowe intrusion of the San Gabriel Mountains in southwestern California (Tosdal, 1988)

Kd Diorite and gabbro (Triassic?) - Hornblende diorite and gabbro, locally metamorphosed to amphibolite, exposed in Mule and Little Chuckwalla Mountains near south edge of map (Tosdal, 1988; R.E. Powell, U.S. Geological Survey, written commun., 1989). Intruded by Triassic quartz monzonite and monzodiorite (unit kqm). Undated; age based on this intrusive relation and lack of lithologic similarity to older plutonic rocks known in region (Tosdal, 1988). Mixed with gneiss of probable Proterozoic age in Little Chuckwalla Mountains (R.M. Tosdal, U.S. Geological Survey, written commun., 1990)

PzS Sedimentary rocks, undivided (Paleozoic) - Metamorphosed sedimentary rocks of presumed Paleozoic age consisting primarily of calcitic marble, dolomitic marble, calc-silicate rocks, quartzite, and schist. May include some rocks of Triassic and Jurassic age

PEs Sedimentary rocks (Permian to Cambrian) - Complete, or nearly complete, sequences of metamorphosed Permian to Cambrian strata equivalent to units PPs and M€s combined, but too thin to subdivide at map scale 
PPS Sedimentary rocks (Permian and Pennsylvanian) — Variably metamorphosed sedimentary rocks interpreted to correlate with Permian and Pennsylvanian formations of the Colorado Plateau. In descending order, sequence consists of (4) cherty and non-cherty limestone, dolomite, and marble correlated with the Permian Kaibab Limestone; (3) fine-grained quartz sandstone and quartzite correlated with the Permian Coconino Sandstone; (2) quartzitic calc-silicate schist correlated with the Permian Hermit Formation; and (1) calcareous sandstone, quartzite, and calc-silicate rocks correlated with the Permian and Pennsylvanian Supai Formation (Miller, 1970; Hamilton, 1982; Stone and others, 1983; Ballard, 1990; Richard and others, 1993). Thickness of relatively undeformed, unmetamorphosed section in southern Plomosa Mountains is about $575 \mathrm{~m}$ (Miller, 1970); elsewhere, thickness is highly variable because of deformation and metamorphism

M€s Sedimentary rocks (Mississippian to Cambrian)-Metamorphosed sedimentary rocks interpreted to correlate with Mississippian to Cambrian formations of the Colorado Plateau. Where best exposed in Little Maria and southern Plomosa Mountains, sequence consists of, in descending order, (4) massive calcitic marble correlated with the Mississippian Redwall Limestone; (3) massive dolomitic marble of probable Devonian and Cambrian age; (2) schist and thin-bedded quartzite correlated with the Cambrian Bright Angel Shale; and (1) feldspathic quartzite and conglomeratic quartzite correlated with the Cambrian Tapeats Sandstone (Miller, 1970; Hamilton, 1982; Stone and others, 1983; Ballard, 1990; Richard and others, 1993). Thickness of relatively undeformed, unmetamorphosed section in southern Plomosa Mountains is about 290 m (Miller, 1970); elsewhere, thickness is highly variable because of deformation and metamorphism

YXg Granite and granitic augen gneiss (Mesoproterozoic and Paleoproterozoic?) —Coarse-grained granite and augen gneiss commonly characterized by phenocrysts or porphyroblasts of potassium feldspar 1 to $5 \mathrm{~cm}$ long. U-Pb zircon age in Big Maria Mountains is about 1.4 giga-annum (L.T. Silver, oral commun. in Hamilton, 1982); elsewhere, unit could include older rocks as well. Depositionally overlain by strata correlated with Tapeats Sandstone (basal part of unit M€s)

Xgn Gneiss and amphibolite (Paleoproterozoic) - Diverse gneissic and plutonic rocks in Riverside, Big Maria, and Little Maria Mountains including biotite gneiss, hornblende gneiss, schist, and amphibolite (Hamilton, 1964, 1982, 1984). Locally includes phyllonitic gneiss interpreted to stratigraphically underlie overturned Paleozoic rocks (Ballard, 1990)

Xgd Granodiorite (Paleoproterozoic) — Dark-colored, medium-grained, equigranular granodiorite in the southern Plomosa Mountains; moderately to highly fractured. U-Pb zircon age of 1,730 to 1,750 Ma (L.T. Silver, cited in Miller, 1970)

Xs Schist (Paleoproterozoic) - Fine-grained, micaceous schist and quartzite in Dome Rock Mountains

Xv Metavolcanic rocks (Paleoproterozoic) - Very fine grained, light- to dark-gray, felsic hornfels typically containing sparse quartz phenocrysts 1 to $2 \mathrm{~mm}$ in diameter. Rocks range from massive to compositionally banded on a decimeter to meter scale, with irregular lenticular lithosomes inferred to represent transposed primary lithologic units

\section{Acknowledgments}

Ryan Crow created python scripts that were invaluable in converting the geologic map database into the GeMS schema (https://github.com/rcrow) and creating metadata. Tracey Felger prepared the final database package for publication.

\section{References Cited}

Arizona Gold Corp., 2020, Copperstone Mine (website), accessed January 5, 2021, at https://www.arizona-gold.com/copperstone/.

Ballard, S.N., 1990, The Mesozoic structural evolution of the Little Maria Mountains, Riverside County, California: Santa Barbara, Calif., University of California, Ph.D. dissertation, 380 p.

Barth, A.P., Tosdal, R.M., and Wooden, J.L., 1990, A petrologic comparison of Triassic plutonism in the San Gabriel and
Mule Mountains, southern California: Journal of Geophysical Research, v. 95, no. B12, p. 20075-20096, https://doi. org/10.1029/JB095iB12p20075.

Barth, A.P., Wooden, J.L., Jacobson, C.E., and Probst, K., 2004, $\mathrm{U}-\mathrm{Pb}$ geochronology and geochemistry of the McCoy Mountains Formation, southeastern California-A Cretaceous retroarc foreland basin: Geological Society of America Bulletin, v. 116, p. 142-153, https://doi.org/10.1130/B25288.1.

Boettcher, S.S., Mosher, S., and Tosdal, R.M., 2002, Structural and tectonic evolution of Mesozoic basement-involved fold nappes and thrust faults in the Dome Rock Mountains, Arizona, in Barth, A., ed., Contributions to the crustal evolution of the southwestern United States: Geological Society of America Special Paper 365, p. 73-97, https://doi.org/10.1130/0-8137-2365-5.73.

Dalrymple, G.B., 1979, Critical tables for conversion of K-Ar ages from old to new constants: Geology, v. 7, p. 558-560, https:// doi.org/10.1130/0091-7613(1979)7\%3C558:CTFCOK\%3E2.0 .CO;2. 
Fackler-Adams, B.N., Busby, C.J., and Mattinson, J.M., 1997, Jurassic magmatism and sedimentation in the Palen Mountains, southeastern California-Implications for regional tectonic controls on the Mesozoic continental arc: Geological Society of America Bulletin, v. 109, p. 1464-1484.

Flansburg, M.E., Stockli, D.F., and Singleton, J.S., 2019, Dating ductile deformation in the Maria fold-and-thrust belt with apatite and zircon U-Pb geochronometry, Big Maria and Riverside Mountains, southeastern California: Geological Society of America Abstracts with Programs, v. 51, no. 5, https://doi. org/10.1130/abs/2019AM-337873.

Gootee, B.F., Pearthree, P.A., and Johnson, B.J., 2017, Geologic map of the Moon Mountain SE and western edge of the Bouse SW 71/2' quadrangles, La Paz County, Arizona: Arizona Geological Survey Digital Geologic Map 122 (DGM-122), scale $1: 24,000$.

Hamilton, W., 1964, Geologic map of the Big Maria Mountains NE quadrangle, Riverside County, California, and Yuma County, Arizona: U.S. Geological Survey Geologic Quadrangle 350, scale 1:24,000, https://doi.org/10.3133/gq350.

Hamilton, W., 1982, Structural evolution of the Big Maria Mountains, northeastern Riverside County, southeastern California, in Frost, E.G., and Martin, D.L., eds., Mesozoic-Cenozoic tectonic evolution of the Colorado River region, California, Arizona, and Nevada: San Diego, Calif., Cordilleran Publishers, p. 1-27.

Hamilton, W., 1984, Generalized geologic map of the Big Maria Mountains region, northeastern Riverside County, southeastern California: U.S. Geological Survey Open-File Report 84-407, scale 1:48,000, https://doi.org/10.3133/ofr84407.

Harding, L.E., 1980, Petrology and tectonic setting of the Livingston Hills Formation, Yuma County, Arizona, in Jenney, J.P., and Stone, C., eds., Studies in western Arizona: Arizona Geological Society Digest 12, p. 135-145.

Harding, L.E., 1982, Tectonic significance of the McCoy Mountains Formation, southeastern California and southwestern Arizona: Tucson, Ariz., University of Arizona, Ph.D. dissertation, $197 \mathrm{p}$.

Harding, L.E., and Coney, P.J., 1985, The geology of the McCoy Mountains Formation, southeastern California and southwestern Arizona: Geological Society of America Bulletin, v. 96, p. 755-769.

Haxel, G.B., Jacobson, C.E., and Wittke, J.H., 2015, Mantle peridotite in newly discovered far-inland subduction complex, southwest Arizona - Initial report: International Geology Review, v. 57, nos. 5-8, p. 871-892, https://doi.org/10.1080/002 06814.2014.928916.

Johnson, B.J., Gootee, B.F., Pearthree, P.A., and Ferguson, C.A., 2017, Geologic map of the Middle Camp Mountain 71/2' quadrangle, La Paz County, Arizona: Arizona Geological Survey Digital Geologic Map 121 (DGM-121), scale 1:24,000.

Knapp, J.K., 1989, Structural development, thermal evolution, and tectonic significance of a Cordilleran basement thrust terrane, Maria fold and thrust belt, west-central Arizona: Cambridge, Mass., Massachusetts Institute of Technology, Ph.D. dissertation, $262 \mathrm{p}$.

Martin, D.L., Krummenacher, D., and Frost, E.G., 1982, K-Ar geochronologic record of Mesozoic and Tertiary tectonics of the Big Maria-Little Maria-Riverside Mountains terrane, in
Frost, E.G., and Martin, D.L., eds., Mesozoic-Cenozoic tectonic evolution of the Colorado River region, California, Arizona, and Nevada: San Diego, Calif., Cordilleran Publishers, p. 519-557. Miller, F.K., 1970, Geologic map of the Quartzsite quadrangle, Yuma County, Arizona: U.S. Geological Survey Geologic Quadrangle 841, scale 1:62,500, https://doi.org/10.3133/gq841.

Miller, F.K., and McKee, E.H., 1971, Thrust and strike-slip faulting in the Plomosa Mountains, southwestern Arizona: Geological Society of America Bulletin, v. 82, p. 717-722.

Pelka, G.J., 1973, Geology of the McCoy and Palen Mountains, southeastern California: Santa Barbara, Calif., University of California, Ph.D. dissertation, 162 p.

Reynolds, S.J., Spencer, J.E., Asmerom, Y., DeWitt, E., and Laubach, S.E., 1989, Early Mesozoic uplift in west-central Arizona and southeastern California: Geology, v. 17, p. 207-211.

Reynolds, S.J., Spencer, J.E., Richard, S.M., and Laubach, S.E., 1986, Mesozoic structures in west-central Arizona, in Beatty, B., and Wilkinson, P.A.K., eds., Frontiers in geology and ore deposits of Arizona and the southwest: Arizona Geological Society Digest, v. 16, p. 35-51.

Richard, S.M., 1993, Palinspastic reconstruction of southeastern California and southwestern Arizona for the middle Miocene: Tectonics, v. 12, no. 4, p. 830-854, https://doi. org/10.1029/92TC02951.

Richard, S.M., Ballard, S.N., Boettcher, S.S., Hamilton, W.B., Hoisch, T.D., and Tosdal, R.M., 1994, Mesozoic tectonics of the Maria belt, west-central Arizona and southeastern California, in McGill, S.F., and Ross, T.M., eds., Geological investigations of an active margin: Redlands, Calif., San Bernardino County Museum Association (guidebook for Geological Society of America Cordilleran Section 27th Annual Meeting), p. 272-292.

Richard, S.M., Spencer, J.E., Tosdal, R.M., and Stone, P., 1993, Preliminary geologic map of the southern Plomosa Mountains, La Paz County, Arizona: Arizona Geological Survey Open-File Report 93-9, scale 1:24,000.

Salem, A.C., 2009, Mesozoic tectonics of the Maria fold and thrust belt and McCoy basin — an examination of polyphase deformation and synorogenic response: Albuquerque, N. Mex., University of New Mexico, Ph.D. dissertation, 260 p.

Scarborough, R., and Meader, N., 1983, Reconnaissance geology of the northern Plomosa Mountains: Arizona Geological Survey Open-File Report 83-24, 35 p.

Scarborough, R., and Meader, N., 1989, Geologic map of northern Plomosa Mountains, Yuma County, Arizona: Arizona Geological Survey Contributed Map CM-89-D, scale 1:24,000.

Shafiqullah, M., Damon, P.E., Lynch, D.J., Reynolds, S.J., Rehrig, W.A., and Raymond, R.H., 1980, K-Ar geochronology and geologic history of southwestern Arizona and adjacent areas, in Jenney, J.P., and Stone, C., eds., Studies in western Arizona: Arizona Geological Society Digest 12, p. 201-260.

Spencer, J.E., 1984, Geometry of low-angle normal faults in west-central Arizona: Arizona Bureau of Geology and Mineral Technology Fieldnotes, v. 14, no. 3, p. 6-8.

Spencer, J.E., Duncan, J.T., and Burton, W.D., 1988, The Copperstone mine-Arizona's new gold producer: Arizona Bureau of Geology and Mineral Technology Fieldnotes, v. 18, no. 2, p. 1-3.

Spencer, J.E., Pearthree, P.A., Gootee, B.F., and Tosdal, R.M., 2016, Geologic map of the Dome Rock Mountains SW 71/2' 
quadrangle, La Paz County, Arizona: Arizona Geological Survey Digital Geologic Map 116 (DGM-116), scale 1:24,000.

Spencer, J.E., and Reynolds, S.J., 1991, Tectonics of midTertiary extension along a transect through west central Arizona: Tectonics, v. 10, no. 6, p. 1204-1221, https://doi. org/10.1029/91TC01160.

Spencer, J.E., Richard, S.M., Gehrels, G.E., Gleason, J.D., and Dickinson, W.R., 2011, Age and tectonic setting of the Mesozoic McCoy Mountains Formation in western Arizona, USA: Geological Society of America Bulletin, v. 123, nos. 7-8, p. 1258-1274, https://doi.org/10.1130/B30206.1.

Spencer, J.E., Singleton, J.S., Strickland, E., Reynolds, S.J., Love, D., Foster, D.A., and Johnson, R., 2018, Geodynamics of Cenozoic extension along a transect across the Colorado River extensional corridor, southwestern USA: Lithosphere, v. 10, no. 6, p. 743-759, https://doi.org/10.1130/L1002.1.

Spencer, J.E., Youberg, A., Love, D., Pearthree, P.A., Steinke, T.R., and Reynolds, S.J., 2015, Geologic map of the Bouse and Ibex Peak 71/2' quadrangles, La Paz County, Arizona (ver. 2.0): Arizona Geological Survey Digital Geologic Map 107 (DGM107), scale 1:24,000.

Stone, P., 1990, Preliminary geologic map of the Blythe 30' by 60' quadrangle, California and Arizona: U.S. Geological Survey Open-File Report 90-497, scale 1:100,000, https://doi. org/10.3133/ofr90497.

Stone, P., 2006a, Database for the east half of "Preliminary geologic map of the Blythe 30 ' by 60 ' quadrangle, California and Arizona": U.S. Geological Survey Data Series 225, https://doi. org/10.3133/ds225.

Stone, P., 2006b, Geologic map of the west half of the Blythe 30' by 60' quadrangle, Riverside County, California, and La Paz County, Arizona: U.S. Geological Survey Scientific Investigations Map 2922, scale 1:100,000, 21-p. pamphlet, https://doi. org/10.3133/sim 2922 .

Stone, P., Howard, K.A., and Hamilton, W., 1983, Correlation of metamorphosed Paleozoic strata of the southeastern Mojave Desert region, California and Arizona: Geological Society of America Bulletin, v. 94, no. 10, p. 1135-1147, https://doi. org/10.1130/0016-7606(1983)94\%3C1135:COMPSO\%3E2.0 $\mathrm{CO} ; 2$.

Stone, P., Page, V.M., Hamilton, W., and Howard, K.A., 1987, Cretaceous age of the upper part of the McCoy Mountains Formation, southeastern California and southwestern Arizona, and its tectonic significance; reconciliation of paleobotanical and paleomagnetic evidence: Geology, v. 15, no. 6, p. 561-564, https://doi.org/10.1130/0091-7613(1987)15\%3C561:CAOTUP $\% 3 \mathrm{E} 2.0 . \mathrm{CO} ; 2$.

Stone, P., and Pelka, G.J., 1989, Geologic map of the PalenMcCoy Wilderness Study Area and vicinity, Riverside County,
California: U.S. Geological Survey Miscellaneous Field Studies Map 2092, scale 1:62,500, https://doi.org/10.3133/mf2092.

Stone, P., Spencer, J.E., and Beard, L.S., 2022, Digital data for the preliminary bedrock geologic map of the Blythe 30' x 60' quadrangle, California and Arizona: U.S. Geological Survey data release, https://doi.org/10.5066/P9YUU64Z.

Stoneman, D.A., 1985a, Geologic map of the Plomosa Pass area, northern Plomosa Mountains, La Paz County, Arizona: Arizona Geological Survey Miscellaneous Map MM-85b, scale 1:12,000.

Stoneman, D.A., 1985b, Structural geology of the Plomosa Pass area, northern Plomosa Mountains, La Paz County, Arizona: Tucson, Ariz., University of Arizona, M.S. thesis, 99 p.

Strickland, E.D., Singleton, J.S., Griffin, A.T.B., and Seymour, N.M., 2017, Geologic map of the northern Plomosa Mountains metamorphic core complex, Arizona: Arizona Geological Survey Contributed Map CM-17-A, scale 1:10,000.

Strickland, E.D., Singleton, J.S., and Haxel, G.B., 2018a, Orocopia Schist in the northern Plomosa Mountains, west-central Arizona-A Laramide subduction complex exhumed in a Miocene metamorphic core complex: Lithosphere, v. 10, no. 6, p. 723-742, https://doi.org/10.1130/L742.1.

Strickland, E.D., Singleton, J.S., Wyatt, M.R., and Seymour, N.M., 2018b, Post-middle Miocene transtension in the Plomosa Mountains and development of the La Posa Plain, west-central Arizona: Geological Society of America Abstracts with Programs, v. 50, no. 5, https://doi.org/10.1130/abs/2018RM-314259.

Tosdal, R.M., 1988, Mesozoic rock units along the Late Cretaceous Mule Mountains thrust system, southeastern California and southwestern Arizona: Santa Barbara, Calif., University of California, Ph.D. dissertation, 365 p.

Tosdal, R.M., Haxel, G.B, and Wright, J.E., 1989, Jurassic geology of the Sonoran Desert region, southern Arizona, southeastern California, and northernmost Sonora-Construction of a continental-margin magmatic arc, in Jenney, J.P., and Reynolds, S.J., eds., Geologic evolution of Arizona: Arizona Geological Society Digest 17, p. 397-434.

Tosdal, R.M., and Stone, P., 1994, Stratigraphic relations and U-Pb geochronology of the Upper Cretaceous upper McCoy Mountains Formation, southwestern Arizona: Geological Society of America Bulletin, v. 106, p. 476-491.

Tosdal, R.M., and Wooden, J.L., 2015, Construction of the Jurassic magmatic arc, southeast California and southwest Arizona, in Anderson, T.H., Didenko, A.N., Johnson, C.L., Khanchuck, A.I., and MacDonald, J.H., Jr., eds., Late Jurassic margin of Laurasia-A record of faulting accommodating plate rotation: Geological Society of America Special Paper 513, p. 189-221.

Yeats, K.J., 1985, Geology and structure of the northern Dome Rock Mountains, La Paz County, Arizona: Tucson, Ariz., University of Arizona, M.S. thesis, 123 p. 